\title{
Clinical and regulatory protocols for the management of impaired vision in the public health care network
}

\author{
Protocolos clínicos e de regulação para condução da dificuldade visual na rede pública de saúde
}

Jayter Silva Paula ${ }^{1}$, João Marcello Fortes Furtado², Fabiano Cade Jorge², Eduardo Melani Rocha ${ }^{1}$, Ingrid U. Scott ${ }^{3}$, Luciane Loures dos Santos ${ }^{4}$, Maria de Lourdes Veronese Rodrigues ${ }^{1}$, José Sebastião dos Santos ${ }^{5}$

\begin{abstract}
Purpose: To describe the procedures used in developing Clinical and Regulatory Protocols for primary care teams to use in the management of the most common scenarios of impaired vision in Southern Brazil.

Methods: A retrospective review of 1.333 referral forms from all primary care practitioners was performed in Ribeirão Preto city, during a 30-day period. The major ophthalmic diagnostic categories were evaluated from those referrals forms. The Clinical and Regulatory Protocols development process was held afterwards and involved scientific cooperation between a university and the health care system, in the form of workshops attended by primary care practitioners and regulatory system team members composed of health care administrators, ophthalmologists, and professors of ophthalmology and social medicine.

Results: The management of impaired vision was chosen as the theme, since it accounted for $43.6 \%$ of the ophthalmology-related referrals from primary care providers of Ribeirão Preto. The Clinical and Regulatory Protocols developed involve distinctive diagnostic and therapeutic interventions that can be performed at the primary care level and in different health care settings. The most relevant clinical and regulatory interventions were expressed as algorithms in order to facilitate the use of the Clinical and Regulatory Protocols by health care practitioners.

Conclusions: These Clinical and Regulatory Protocols could represent a useful too for health systems with universal access, as well as for health care networks based on primary care and for regulatory system teams. Implementation of these Clinical and Regulatory Protocols can minimize the disparity between the needs of patients with impaired vision and the treatment modalities offered, resulting in a more cooperative health care network.
\end{abstract}

Keywords: Vision disorders; Delivery of health care; Public Health; Health Services; Primary health care; Health systems; Clinical protocols

\section{RESUMO}

Objetivo: Descrever os procedimentos utilizados no desenvolvimento de Protocolos Clínicos e de Regulação, para equipes de atenção primária à saúde, voltados à condução dos cenários clínicos mais comuns de dificuldade visual observados na região sudeste do Brasil.

Métodos: Realizou-se a revisão retrospectiva de 1.333 guias de encaminhamento advindas de todos os profissionais da atenção primária da cidade de Ribeirão Preto, durante um período de 30 dias. As principais categorias diagnósticas oftalmológicas foram avaliadas nessas guias de referência. O processo de desenvolvimento dos Protocolos Clínicos e de Regulação ocorreu na sequência e envolveu a cooperação científica entre a universidade e o sistema de saúde, sob a forma de oficinas com médicos da atenção primária emembros da equipe do sistema de regulação, composto por gestores desaúde, oftalmologistas, além de professores de oftalmologia e medicina social.

Resultados: A dificuldade visual foi escolhida como tema central, uma vez que representou 43,6\% dos encaminhamentos oftalmológicos advindos de serviços de atenção primária de Ribeirão Preto. Os Protocolos Clínicos e de Regulação desenvolvidos envolveram diferentes procedimentos diagnósticos e terapêuticos que podem ser executados na atenção primária e outros níveis ou contextos de cuidados à saúde. As intervenções clínicas e deencaminhamento mais relevantes foram expressas como algoritmos, a fim defacilitar a utilização do protocolo pelos profissionais da saúde.

Conclusões: Os Protocolos Clínicos e de Regulação poderão representar uma ferramenta útil para os sistemas de saúde que contam com acesso universal, bem como para as redes de cuidados de saúde baseadas na atenção primária e nos sistemas de regulação. A implementação de Protocolos Clínicos e de Regulação poderá minimizar a disparidade entre as necessidades dos pacientes com dificuldade visual e as formas de condução de casos oftalmológicos, resultando em uma rede de saúde mais eficiente.

Descritores: Transtornos da visão; Assistência à saúde; Saúde Pública; Serviços de Saúde; Atenção primária à saúde; Sistema de saúde; Protocolos clínicos

\section{INTRODUCTION}

The Brazilian Sistema Único de Saúde (SUS, Unified Health Care System), established in 1988, provides universal, decentralized access to health care and has increasingly become a hierarchically complex network based on primary health care ${ }^{(1,2)}$.

Although implementation of the SUS has amplified the primary health care structure, inefficient clinical interventions and poor primary care coordination have resulted in excessive demand for specialized and emergency care services ${ }^{(3)}$. Measures adopted in order to streamline access to various health care services include the implementation of the Regulatory System (RS), which is aimed at mapping the allocation of health care resources and structuring the various regulatory bodies. Non-emergency cases that require specialty care are referred to a RS team via the heath care network.
Submitted for publication: March 10, 2011

Accepted for publication: April 21, 2011

Study was carried out at the Ribeirão Preto School of Medicine - University of São Paulo

Professor, Department of Ophthalmology, Otorhinolaryngology and Head and Neck Surgery. Ribeirão Preto School of Medicine, Universidade de São Paulo - USP - Ribeirão Preto (SP), Brazil.

2 Physician, Department of Ophthalmology, Otorhinolaryngology and Head and Neck Surgery.

Ribeirão Preto School of Medicine, Universidade de São Paulo - USP - Ribeirão Preto (SP), Brazil.

3 Professor, Departments of Ophthalmology and Public Health Sciences, Penn State College of Medicine, Hershey, Pennsylvania, USA.

Professor, Department of Social Medicine, Ribeirão Preto School of Medicine, Universidade de São

Paulo - USP - Ribeirão Preto (SP), Brazil.

5 Professor, Department of Surgery and Anatomy, Ribeirão Preto, School of Medicine Universidade

de São Paulo - USP - Ribeirão Preto (SP), Brazil.
Funding: This study was supported by CNPq, FAEPA and Fundação Waldemar Barnsley Pessoa. Disclosure of potential conflicts of interest: Paula JS, None; Furtado JMF, None; Jorge FC, None; Rocha EM, None; Scott IU, None; dos Santos LL, None; Rodrigues MLV, None; dos Santos JS, None.

Correspondence address: Jayter Silva Paula. Department of Ophthalmology, Otorhinolaryngology and Head and Neck Surgery. Ribeirão Preto School of Medicine - University of São Paulo Av. Bandeirantes, 3900 - 12‥ Andar - Ribeirão Preto - SP - 14049-900 - Brazil. E-mail: jspaula@fmrp.usp.br 
Medical teams and users can also consult the various RS units, the emergency unit in particular, by telephone, internet and fax ${ }^{(3-5)}$.

Ineffective ophthalmologic interventions and limited knowledge of community eye health on the part of primary care providers have led to various problems related to local treatment and referral of ophthalmologic cases. The objective of the present study was to evaluate the major ocular conditions in patients referred to health care clinics, as well as to present Clinical and Regulatory Protocols (CRPs) for the treatment and management of those conditions, developed through scientific cooperation between the university and the health care system.

\section{METHODS}

\section{Selection of themes for developing CRPs}

The CRPs presented here were developed by ophthalmologists, general practitioners, nurses and representatives of the Municipal Health Department of the city of Ribeirão Preto, Brazil. The CRP themes were categorized as "mixed" (when no specified ocular diagnosis was mentioned) or "authentic" (when a specific ophthalmologic problem/diagnosis was described or suspected) based on ophthalmic cases included on the referral forms reviewed. Treatment, conduction or any kind of clinical resolution proposed for a specific theme implied in the use of several health care network elements and other social resources.

The themes were analyzed and selected, in workshops, by a team composed of two primary care practitioners (family physicians) and two specialized health practitioners (ophthalmologists) associated with the University of São Paulo (a matrix care team) and an RS team, composed of three health care administrators. In order to identify the major ocular problems, we surveyed all ophthalmic patients referred to Ribeirão Preto Municipal Health Department clinics in August of 2007. The themes selected are representative of the most prevalent problems in the health care network.

\section{Guidelines for CRP DeVelopment}

Each CRP defines the clinical dimension of a given theme in terms of the various health care network elements involved, as well as stating whether and why specialized services of moderate or high complexity must be provided. The CRP format includes a brief introduction of the theme, including clinical findings setting limits for each service provided. Relevant observations can be attached together with bibliographic references. In accordance with the recommendations of the World Health Organization ${ }^{(6)}$ and the Pan American Health Organization, the guidelines used for CRP development are based on scientific evidence, collected from the systematic reviews published by the Brazilian Cochrane Centre and PubMed citations, as well as from publications describing Brazilian health care policies related to treatment allocation and regulation of user access to the SUS ${ }^{(7-11)}$

The CRPs were developed by the matrix team under the supervision of a technical group (composed of two professors of ophthalmology and one professor of social medicine) designated to monitor the methodological aspects. The content of each protocol mirrors the multidisciplinary intervention undertaken to handle a specific health-related problem and is in accordance with the policies of the national and local health care networks.

The rationale for regulating access to health care services is based on using primary care as a portal of entry, both in terms of elective needs and referral to other health providers ${ }^{(2-11)}$. Emergency cases of low complexity can be addressed at the primary care level, whereas severe cases must be referred to emergency care facilities as required by the regulatory guidelines ${ }^{(3-5)}$.

The technical and regulatory components of the CRPs reflect the interactions among the facilities (hospitals, health care clinics, ambulance services, etc.) available in the community under study, taking into consideration their complexity and capacity, which may be useful as an example of the health system as a whole. Clinically, CRPs for impaired vision are grounded in the description of ophthalmic signs and symptoms, or of the disease itself. The CRPs presented here were revised by the technical group linked to the Ribeirão Preto Municipal Health Department and services provided by the Department itself.

\section{Definition OF IMPAIRED VISION}

Impaired or blurred vision, in one or both eyes, should be preferentially measured using a logMAR chart (visual acuity of a normal eye was then recorded as decimals, for example, 1.0). Normal visual acuity can vary according to patient age, as follows: 6 months to 2 years - fixate and maintain steady fixation on light and objects; 2 to 5 years - 0.5 or better; and older than 5 years -0.7 or better and a difference of less than two lines between eyes. Patients who do not reach these levels of visual acuity are classified as having impaired vision. The findings of the clinical history, examination parameters and results of visual acuity measurement, should all be addressed on the referral form, together with individual patient data, prior to the proposal of diagnoses. The RS team uses these forms to refer patients to a higher level of the SUS for an ophthalmologic consultation.

\section{CRPS FOR VISUAL IMPAIRMENT}

Considering the SUS administrative planning and the multidisciplinary research goals, CRPs for visual impairment were developed according to the methods proposed for the five most common clinical scenarios.

\section{RESULTS}

\section{Principal OPHTHALmological Conditions in CASES REFERRED FROM HEALTH CARE CLINICS}

In evaluating the records related to all cases referred for ophthalmological treatment during the study period, we found the principal conditions to be suspected are refractive error (in 23.1\%) and undiagnosed impaired vision (in $20.5 \%$ ), although $39.7 \%$ of the case files were incomplete (Table 1). Since the majority of refractive error suspects are accompanied by some degree of impaired or blurred vision, 43.6 percent of the cases could be said to be associated with a diagnosis of impaired vision. Based on these findings, we decided to create CRPs for impaired vision and the various conditions with which it is associated. Table 2 details the CRP for each scenario, and Figure 1 provides an overview.

Table 1. Principal vision problems observed on referral forms from primary care physicians for ophthalmologic services during a one-month period in the city of Ribeirão Preto, Brazil

\begin{tabular}{lrr}
\hline Diagnosis & \multicolumn{2}{c}{ Referrals n (\%) } \\
\hline Missing data & 529 & $(39.7 \%)$ \\
Refractive errors & 308 & $(23.1 \%)$ \\
Visual impairment & 273 & $(20.5 \%)$ \\
Retinal problems & 55 & $(4.1 \%)$ \\
Cataract & 31 & $(2.3 \%)$ \\
Other (not specified) & 29 & $(2.2 \%)$ \\
Pterygium & 27 & $(2.0 \%)$ \\
Headache & 18 & $(1.4 \%)$ \\
Conjunctivitis & 17 & $(1.3 \%)$ \\
Strabismus & 16 & $(1.2 \%)$ \\
Eyelids and adnexa problems & 10 & $(0.8 \%)$ \\
Glaucoma & 7 & $(0.5 \%)$ \\
Ocular pain & 5 & $(0.4 \%)$ \\
Red eye & 5 & $(0.4 \%)$ \\
Ocular trauma & 3 & $(0.2 \%)$ \\
Total & $1333(100.0 \%)$ \\
\hline
\end{tabular}


Table 2. Clinical and regulatory protocol for ophthalmological scenarios in the primary health care

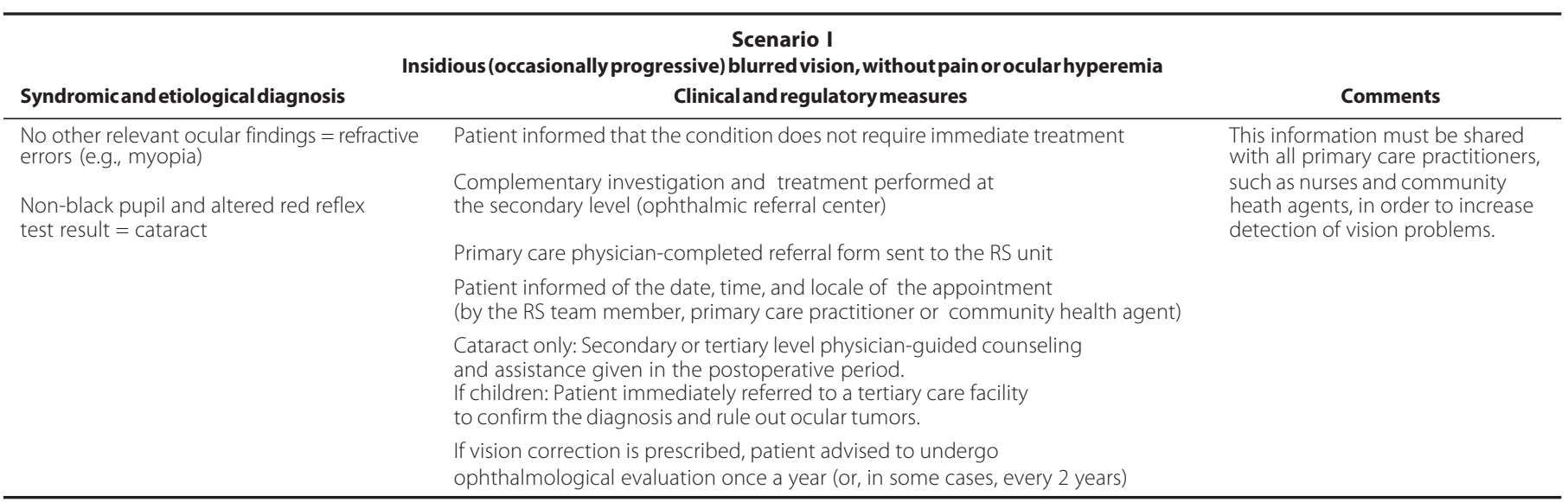

\section{Scenario II}

Blurred vision, with an acute onset (less than 3 days), usually mild, with diffuse ocular hyperemia, with or without secretion, mild pain or foreign body sensation Syndromicand etiological diagnosis

Clinical and regulatory measures

Comments

Purulent discharge, occasionally with eyelid edema $=($ possible) bacterial conjunctivitis

Signs of viral upper respiratory infection, history of contact with conjunctivitis patients, pre-auricular nodules, aqueous/mucous discharge (worse in the morning) or foreign body sensation $=($ possible) viral conjunctivitis

Aqueous discharge, occasionally with conjunctival or eyelid edema and excessive itching = (possible $)$ allergic conjunctivitis

\section{Bacterial conjunctivitis: ocular hygiene using saline solution} cold wet compresses and antibiotic eye drops

Viral conjunctivitis: ocular hygiene using saline solution, cold wet compresses and artificial tears (1 drop/2 h or as needed)

Allergic conjunctivitis: cold wet compresses and artificial tears to relieve itching

Patients advised to return to the primary heath care facility if worsening of blurred vision occurs, or if the symptoms do not lessen within 4 days, at which point they are referred to a secondary level facility (ophthalmic referral center)

Primary care physician-completed referral form sent to the RS unit

Patient informed of the date, time, and locale of the appointment (by the RS team member, primary care practitioner or community health agent)

Bacterial and viral conjunctivitis: Patient advised to avoid contact with other people for 7 days, due to the risk of transmission. If necessary, a statement regarding the clinical condition is provided for professional purposes
Cases of decreased visual acuity due to corneal opacities can be referred for specialized (secondary level) treatment, since corneal infection following bacterial conjunctivitis (keratitis), which presents as severe pain and markedly decreased visual acuity, is a possibility. These cases should be given immediate attention via the RS. Due to the risk of secondary glaucoma and cataract, corticosteroid eye drops are not recommended in cases of allergic conjunctivitis, although they can be used after specialized evaluation at a referral (secondary level) facility. If other causes with different presentations, such as Chlamydia trachomatis (including trachoma), herpes simplex virus, gonococcus, etc., are suspected, they should be investigated at the secondary level. This information must be shared with all primary care practitioners, such as nurses and community heath agents, in order to increase detection of vision problems.

\section{Scenario III}

Moderate or severe decrease in the visual acuity, with ocular hyperemia around the cornea, accompanied by severe pain, typically unilateral; altered pupillary light-reflex test results and altered corneal color/brightness, with or without proptosis

Syndromic and etiological diagnosis

Diffuse ocular or circumcorneal hyperemia and excessive tearing; corneal haze with or without a history of foreign body or contact lens use; Positive (green) fluorescein corneal staining $=$ corneal ulcer (keratitis)

Severe unilateral ocular pain with periocular radiation, accompanied by headache, nausea, vomiting, pupillary dilation and perception of colored halos around lights, without healing when anesthetic is instilled, and globe hard to palpation = acute glaucoma

Severely blurred vision with mild pain and photophobia, with or without circumcorneal hyperemia $=$ uveitis

Severe hyperemia and painful eye, with history of ocular trauma or previous ophthalmological surgery = endophthalmitis

\section{Clinical and regulatory measures}

Patient referred to an ophthalmologist

Patient immediately referred to a tertiary care facility to confirm the diagnosis and prescribe appropriate treatment

Primary care physician completes the referral order manually or electronically and makes phone contact with the RS

Patient advised that the condition can worsen if not treated appropriately

Patient followed up in accordance with instructions given by tertiary level physicians

\section{Comments}

Due to the possibility of severe ocular sequelae or neoplastic diseases, none these diseases should be managed at the primary care level; nor should other rare diseases that can present with these severe signs and symptoms. Since such cases can require the use of more highly complex diagnostic tools, available exclusively in tertiary facilities, immediate referral for ophthalmological examination is imperative. 


\section{Scenario IV}

Mild blurred vision, focal ocular hyperemia and foreign body sensation, without secretion or significant ocular pain Syndromicand etiological diagnosis Clinical and regulatory measures

\begin{tabular}{|c|c|c|}
\hline $\begin{array}{l}\text { Reddish fibrovascular tissue, often in the } \\
\text { medial quadrant of the globe, without } \\
\text { corneal involvement = pinguecula } \\
\text { Reddish fibrovascular tissue, often } \\
\text { in the medial quadrant of the globe, } \\
\text { impinging upon the cornea = pterygium } \\
\text { Red spot, nonspecific in shape, } \\
\text { caused by bleeding; can be spontaneous = } \\
\text { subconjunctival hemorrhage }\end{array}$ & $\begin{array}{l}\text { Patient informed that the condition does not require immediate treatment } \\
\text { Cold compresses and artificial tears ( } 1 \text { drop/ } 2 \text { h or as needed) prescribed } \\
\text { Spontaneous subconjunctival hemorrhage: a history of systemic hypertension, } \\
\text { vasculitis or other hematological anomalies should be ruled out. } \\
\text { If no major spontaneous remission occurs within } 7 \text { days, } \\
\text { patient referred to secondary level care } \\
\text { Primary care physician-completed referral form sent to the RS unit }\end{array}$ & $\begin{array}{l}\text { Although pterygium can be surgically } \\
\text { removed, this should be reserved for } \\
\text { very specific cases, due to the risk of } \\
\text { postoperative recurrence. These cases } \\
\text { should be referred as described, and all } \\
\text { details should be explained to the } \\
\text { patient. It is important to instruct } \\
\text { patients with a pinguecula or a } \\
\text { pterygium to avoid exposure to } \\
\text { sunlight, dust and wind by using } \\
\text { sunglasses and hats. }\end{array}$ \\
\hline
\end{tabular}

Scenario V

Mild blurred vision, accompanied by diffuse ocular hyperemia, with increased foreign body sensation; history of foreign body or of high risk activity for foreign body accident (e.g., motorcycle riding without eye protection) Clinical and regulatory measures

Comments

\section{Syndromicand etiological diagnosis}

\section{Foreign body in the bulbar}

conjunctiva, superior fornix

or inferior fornix after

eyelid eversion = conjunctival foreign body

Foreign body on the

corneal surface $=$ corneal foreign body
Patient investigated for ocular perforation, with leakage of intraocular liquid, as well as history of car accident or severe decrease in visual acuity

If ocular perforation is suspected, the patient must be immediately referred to a tertiary care facility

Conjunctival foreign body treated at the primary health care level in the following sequence: foreign body localization; application of anesthetic eye drops (proxymetacaine 1\%, 1 drop); removal of the foreign body with cotton-swabs or saline solution irrigation, after eyelid eversion, if necessary

Corneal foreign must be removed, with appropriate instruments, by an ophthalmologist.

Conjunctival foreign body: foreign bodies that cannot be removed at the primary care level must be managed by an ophthalmologist, prior to which the affected eye is occluded, with ophthalmological (antibiotic) ointment, to comfort and protect

Primary care physician completes the referral order manually or electronically and makes phone contact with the RS

Patient advised that the condition can worsen if not treated appropriately
These cases are serious due to the risk of contamination, which can cause corneal ulcer and/or severe scarring. Finally, patients should be instructed not to remove the foreign body without medical assistance. The continuous use of anesthetic eye drops has deleterious effects and should therefore be prohibited. 


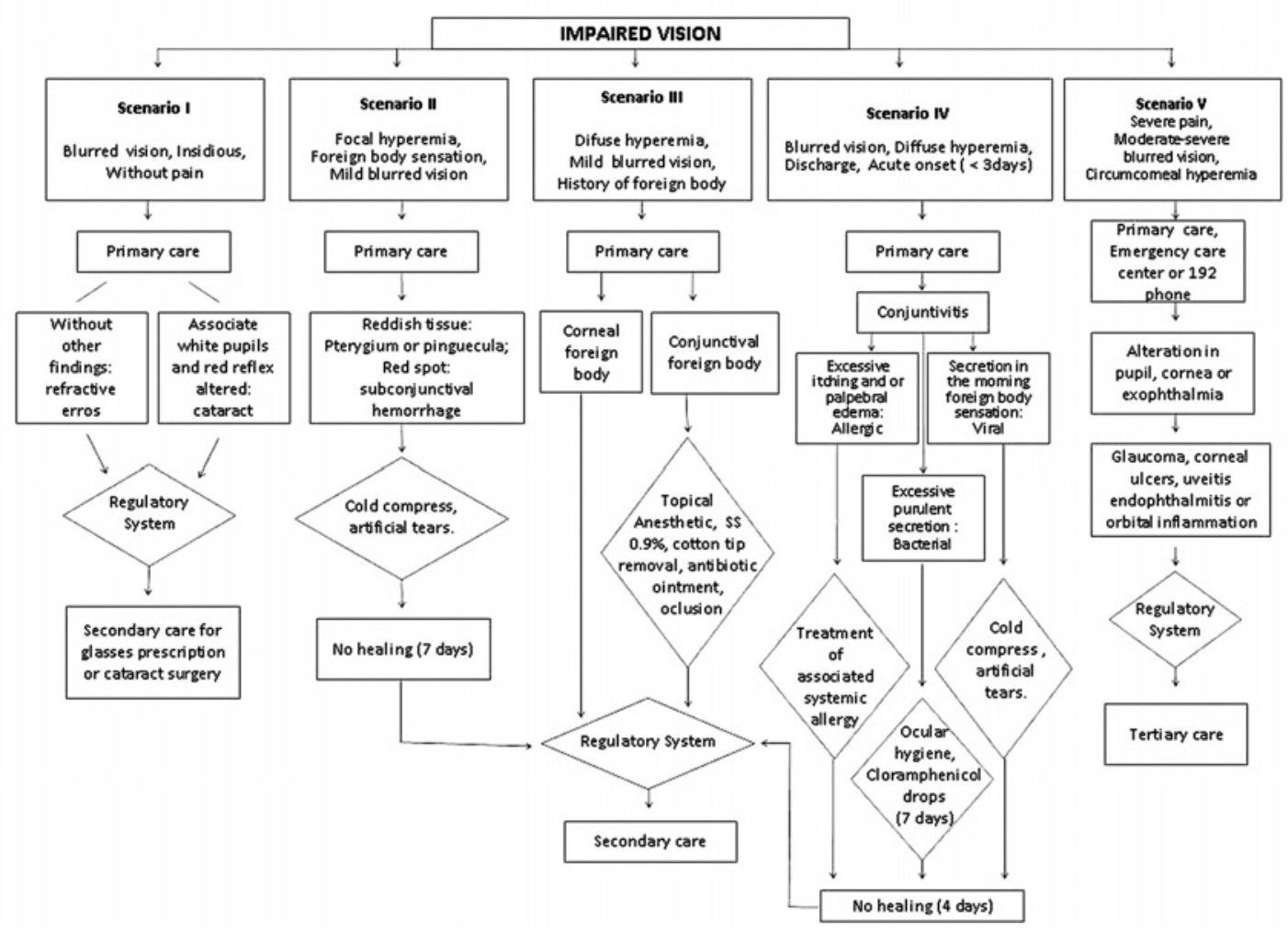

SS= saline solution; Secondary= secondary-care ophthalmological clinic; Tertiary=tertiary-care ophthalmological clinic

Figure 1. Five visual impairment scenarios.

primary care level, being referred for specialized attention only if there is no healing. However, patients presenting with signs and symptoms of cataracts should be sent to secondary or tertiary care for surgery. Therefore, correct diagnoses made at the primary care level could reduce treatment delays.

The inequities between clinical and social conditions, embodied by the inability of some patients to undergo clinical evaluations, exams and procedures, are imposed by a fragmented health care system that lacks coordination and organization. These inequities result in generalized dissatisfaction, treatment delay and wasted resources. Once developed, CRPs for impaired vision need to be validated in order to promote appropriate access to the best quality vision care, defined as receiving clinical eye care from the right professional, at the right time and in the right place.

The CRPs described here can further the understanding of ophthalmological issues by general physicians, promoting accurate diagnosis and rapid movement of patients through the health care system.

\section{CONCLUSIONS}

Impaired vision was a common ophthalmic reason of referrals in the primary care services and the presented CRPs could improve the ophthalmological knowledge in those settings as well as the efficacy of this hierarchical-based referral system.

\section{REFERENCES}

1. Brasil. Ministério da Saúde. Lei nº $8142 / 90$ de 28 de dezembro de 1990. Dispõe sobre a participação da comunidade na gestão do Sistema Único de Sáude (SUS) e sobre as transferências intergovernamentais de recursos financeiros na área da saúde e dá outras providências [Internet]. Brasília; MS; 1990. [citado 2010 Dez 12]. Disponível em: http:// www.jusbrasil.com.br/legislacao/109610/lei-8142-90

2. Starfield B. Primary care: concept, evaluation and policy. New York: Oxford University Press; 1992.
3. Santos JS, Kemp R, Sankarankutty AK, Salgado Jr W, Souza FF, Teixeira AC, et al. Clinical and regulatory protocol for treatment of jaundice in adults and elderly: a support for health care network and regulatory system. Acta Cir Bras. 2008;23 Suppl 1:133-42.

4. Lopes SL, Santos JS, Scarpelini S. The implementation of the medical regulation office and mobile emergency attendance system and its impact on the gravity profile of non-traumatic afflictions treated in a University Hospital:a research study. BMC Health Serv Res. 2007:7:173.

5. Santos JS, Scarpelini S, Brasileiro SL, Ferraz CA, Dalloro ME, Sá MF. Avaliação do modelo de organização da Unidade de Emergência do HCFMRP-USP, adotando, como referência as políticas nacionais de atenção às urgências e de humanização. Medicina (Ribeirão Preto). 2003; 36(2/4):498-515.

6. World Health Organization. Global Programme on Evidence for Health Policy. Guidelines for WHO Guidelines [Internet]. Geneva: WHO; 2003. [cited 2010 Jan 12]]. Available from: http://whqlibdoc.who.int/HQ/2003/EIP_GPE_EQC_2003_1.pdf

7. Brazilian Heath Ministry's. Law number 399; February 22, 2006. [Internet]. Disponível em: http://dtr2001.saude.gov.br/sas/PORTARIAS/Port2006/GM/GM-399.htm

8. Brasil. Ministério da Saúde. Portaria no. 399/GM de 22 de fevereiro de 2006. Divulga o pacto pela saúde 2006-Consolidação do SUS e aprova as diretrizes operacionais do referido pacto [Internet]. Brasília: MS; 2006. [citado 2009 Nov 20]. Disponível em: em: http:// www.mp.go.gov.br/portalweb/hp/2/docs/ma_pga2008_por._399_colegiado _de_gestao.pdf

9. Ribeirão Preto. Prefeitura Municipal de Ribeirão Preto. Secretaria Municipal da Saúde. Plano de saúde de Ribeirão Preto: período 2005-2008. Ribeirão Preto (SP); 2005. [citado em 2006 Fev 24]. Disponível em: http://www.ribeiraopreto.sp.gov.br/ssaude/vigilancia/ planeja/plano05-08. Pdf

10. Brasil. Ministério da Saúde. Portaria n‥ 1101 de 12 de junho de 2002. Estabelece os parâmetros de cobertura assistencial sejam estabelecidos pela Direção Nacional do Sistema Único de Saúde - SUS [Internet]. Brasília: MS; 2002. [citado em 2006 Jul 27]. Disponível em: http://dtr2001.saude.gov.br/sas/PORTARIAS/Port2002/Gm/GM-1101.htm

11. Persaud DD, Jreige S, LeBlanc RP. Enhancing vision care integration: 1. Development of practice algorithms. Can J Ophtalmol. 2004;39(3):219-24.

12. Persaud DD, Jreige S, LeBlanc RP. Enhancing vision care integration: 2 . Implementation of practice algorithms. Can J Ophtalmol. 2004; 39(3):225-33.

13. Hartz ZM, Contandripolus AP. [Comprehensive health care and integrated health services: challenges for evaluating the implementation of a "system without walls"]. Cad Saude Publica. 2004;20 Suppl 2:331-6. Portuguese.

14. ResnikoffS, Pascolini D, Mariotti SP, Pokharel GP. Global magnitude of visual impairment caused by uncorrected refractive errors in 2004. Bull World Health Organ. 2008;86(1):63-70. Comment in: Bull World Health Organ. 2008;86(8): B-C; author reply C. 